\title{
OPINION
}

\section{Dealing with Ambiguity: Johan Maurits, Black Pete and the the Crisis of Dutch Identity ${ }^{*}$}

\author{
Lukas van den Berge
}

\section{Introduction}

A dominant way in which the Dutch think of themselves entails the image of an enlightened nation, too small to be really significant in world politics but nevertheless important as an ethical guiding light for other nations. In recent years, that self-congratulatory image has been severely challenged - not only by the rise of right-wing populist parties and the assassinations of Pim Fortuyn and Theo van Gogh, but also by a growing awareness of the troublesome nature of Dutch colonial history and of patterns of exclusion and oppression in Dutch culture as they have now come to the surface in a globalizing world. ${ }^{1}$ Public debate is dominated by the opposing sides of those who one-sidedly debunk Dutch culture and politics as oppressive and violent and others who persist in the myth of innocent bystandership and enlightened progressivism. Worried about the fierceness of that debate, many scholars and publicists have called for a more nuanced discussion, typically emphasizing the 'grey middle ground' in between black and white opposites. ${ }^{2}$ By way of illustration of the identity crisis that Dutch society is currently dealing with, this short discussion paper starts out by providing the examples of the remembrance of Johan Maurits's governorship of Dutch Brazil (1637-1644) and the stereotyped persona of Black Pete (one of the central figures in an annual children's festival) as two recent objects of heated debate. Subsequently, it explores an alternative way out of the crisis, calling in the help of what may come as a surprising source: ancient Greek tragedy.

\section{Johan Maurits}

Founded in 1621 to disturb the Iberian supremacy in the Americas, the Dutch West India Company (WIC) gained a significant foothold in north-eastern Brazil in 1630, conquering the region of Pernambuco as one of the richest sugar producing areas in the world. Confronted with a lack of settlers from the Low Countries,

* Thanks go out to Mirthe Jiwa, Wouter Veraart and Tamar de Waal for their helpful comments on an earlier draft of this discussion paper.

1 See, e.g., Gloria Wekker, White Innocence: Paradoxes of Colonialism and Race (Durham: Duke University Press, 2016).

2 See, e.g., www.dtbg.nl for the 'Grey Manifesto' published by the academic platform that calls itself 'Dare to be Grey.' 
the WIC had no choice but to turn to local inhabitants to operate the sugarcane plantations. ${ }^{3}$ In order to reconcile Portuguese and Spanish colonists as well as indigenous tribes to the new reality of Dutch rule, the WIC directed its commanders to accord liberty of conscience and private worship to 'Spaniards, Portuguese, and natives of the land, whether they be Roman Catholics or Jews.' ${ }^{4}$ That policy of religious tolerance - sharply contrasting with the missionary zeal of the Portuguese rulers - would soon be personified by Johan Maurits of Nassau-Siegen, who acted as Dutch Brazil's governor between 1637 and 1644. ${ }^{5}$ In Brazil - and especially in Pernambuco - his seven-year reign is still remembered as a short, but marvellous interlude from fierce oppression, a Golden Age that saw the construction of glorious gardens and palaces for the new rulers but also of dams, dikes, bridges contributing to the safety and the welfare of the general population. ${ }^{6}$ Dutch control of the region did not last for long; in 1654, Pernambuco's capital Recife - at the time called Mauritiopolis - was recaptured by the Portuguese. ${ }^{7}$

Carefully building his image as an enlightened humanist prince, Maurits surrounded himself by a large entourage of artists and scientists. Back in Holland, he commissioned a series of books and pamphlets on his great achievements to Caspar Barlaeus, one of the most learned men of his age. Praising Maurits's great wisdom and character, Barlaeus compares him to great ancient statesmen like Solon, Pericles and Augustus. 'He was a strict guardian of rights and justice,' Barlaeus writes, a true 'light in a world of darkness,' applying 'the same laws to citizens of all ranks, to the native Indians and Christians." ${ }^{8}$ As 'a gift to the government of Brazil' he 'devoted his military prowess to freedom (...) and the well-being of mankind,' a source of culture that brought harmony among the peoples. ${ }^{9}$ Barlaeus's hagiographic writings remain silent, however, on Maurits's pivotal role in the establishment of the Dutch slave trade. In need of workers for the sugar plantations, Maurits commissioned his fleet to conquer the Portuguese stronghold of Elmina on the coast of present-day Ghana. From there, his vessels transported more than 20,000 Africans to Brazil, marking the WIC's entry into the lucrative

3 Michiel van Groesen, introduction to The Expansion of Tolerance. Religion in Dutch Brazil (1624-1654), by Jonathan Israel and Stuart B. Schwartz (Amsterdam: Amsterdam University Press, 2007), 8.

4 The translated text of the original regulation is quoted from Jonathan Israel, 'Religious Toleration in Dutch Brazil (1624-1654),' in The Expansion of Tolerance. Religion in Dutch Brazil (1624-1654), by Jonathan Israel and Stuart B. Schwartz (Amsterdam: Amsterdam University Press, 2007), 18.

5 See, e.g., Gerhard Brunn and Cornelius Netusch, eds., Sein Feld war die Welt. Johann Moritz von Nassau-Siegen (1604-1679) (Münster: Waxmann, 2008); Holger Kürbis, Johann Moritz von Nassau-Siegen (Erfurt: Sutton, 2005); Ernst van den Boogaart, ed., in collab. with H.R. Hoetink and P.J.P. Whitehead, Johan Maurits van Nassau-Siegen 1604-1679: A Humanist Prince in Europe and Brazil (Den Haag: Johan Maurits van Nassau Stichting, 1979).

6 Michiel van Groesen, 'Introduction: The Legacy of an Interlude,' in The Legacy of Dutch Brazil, ed. Michiel van Groesen (Cambridge: Cambridge University Press), 1-22.

7 Van Groesen, introduction to The Expansion of Tolerance, 10.

8 Caspar Barlaeus, The History of Brazil under the Governorship of Count Johan Maurits of Nassau, trans. Blanche T. Ebeling Koning (Gainesville: University Press of Florida, 2011), 312; 2.

9 Barlaeus, The History of Brazil, 316; 2; 312. 
transatlantic slave trade that would continue up until the 19 th century. ${ }^{10}$ Ultimately, Dutch ships would carry more than 500,000 slaves from Africa to the new world - adding up to approximately five percent of the total transport of African slaves by European colonial powers. ${ }^{11}$

As a clear example of history's pervasive presentness, Johan Maurits returned to the limelight in January 2018 - making national and international headlines almost four centuries after what has come to be known as the 'Dutch interlude' in north-eastern Brazil. The Mauritshuis - a prominent museum located in Maurits's former private residence in the heart of The Hague - removed Maurits's bust from its lobby, responding to 'the growing public debate about the Dutch colonial past' in general and the WIC's contribution to the transatlantic slave trade in particular. ${ }^{12}$ Determined to provide 'a more nuanced presentation' of his legacy, the museum installed a terracotta statuette of Johan Maurits in one of its galleries as a place where it could offer 'the necessary historical context' of colonialism and slavery. Dismissing the bust's removal as a sign of 'hypersensitivity,' leading politicians like Prime Minister Mark Rutte warned against a 'trend of erasing history,' while Geert Wilders's Partij voor de Vrijheid ('Freedom Party') spoke of a 'politically correct iconoclasm,' referring to the destruction of Catholic art in northern Europe in the 16th century. ${ }^{13}$ Populist politician Thierry Baudet newcomer on the far right - was quick to defy the Mauritshuis's decision as a symptom of 'oikophobia,' the 'repudiation of inheritance and home' that would be 'particularly prevalent among intellectual and political elites' and that would speed up a Spenglerian 'decline of the West.' ${ }^{14}$ The removal of the bust - a plastic copy, in fact, of its original placed in his burial vault in Siegen - was applauded, however, by those who tend to see it as a typical expression of 'colonial nostalgia' or even as clear proof of the 'institutional racism' that would underlie modern Dutch culture. ${ }^{15}$

\section{Black Pete}

The debate on Maurits's bust is clearly connected to a wider discussion on Dutch identity that has caught the public attention especially since the start of the controversy on Black Pete, the black-faced helper of Saint Nicholas, arriving annually

10 Van Groesen, introduction to The Expansion of Tolerance, 8-9.

11 Johannes Postma, The Dutch in the Atlantic Slave Trade (Cambridge: Cambridge University Press, 2008); Piet Emmer, The Dutch Slave Trade (New York: Berghahn Books, 2005).

12 Sander van Walsum, 'Buste van Johan Maurits verbannen naar het depot: slavernijdebat gaf de doorslag,' de Volkskrant, January 16, 2018.

13 Janene Pieters, 'Mauritshuis Offers Free Entry after Commotion over Namesake's Bust,' NL Times, see https://nltimes.nl/2018/01/22/mauritshuis-museum-offers-free-entry-commotionnamesakes-bust (accessed February 23, 2018). See also Gordon Darroch, 'Dutch Museum Reopens Uneasy Debate about Colonial Legacy,' The Guardian, January 25, 2018.

14 Roger Scruton, England and the Need for Nations (London: Civitas, 2004), 36-38; Thierry Baudet, Oikofobie (Amsterdam: Prometheus, 2013).

15 Karwan Fatah-Black, 'Vasthouden aan koloniale nostalgie helpt niemand verder,' NRC Handelsblad, January 12, 2018. 
to the Netherlands in folklore fashion and bringing presents and sweets to children. ${ }^{16}$ In 2013, a letter was sent to the Dutch government by a UN working group, asking for clarification about the Dutch Saint Nicholas tradition. ${ }^{17}$ In an interview, the working group's chair, Jamaican academic Verene Shepherd, described that tradition as a throwback to a cruel colonial past that should be stopped in its present form immediately. ${ }^{18}$ Shepherd's comments were met with an outburst of disdain on social media, with more than one million 'likes' - a record in Dutch social media history - for a Facebook page (Pietitie, i.e. Peteition) that ridiculed and dismissed her critique. ${ }^{19}$ 'Black Pete is black, I cannot change that,' Prime Minister Rutte concisely remarked, thus discharging the stereotyped image of Black Pete as a quite unimportant issue, nothing for the government to be really bothered about. ${ }^{20}$ In recent years, however, the objections of Pete's critics have been taken more seriously. In 2016, the Dutch children's ombudsman stated that the character of Black Pete may contribute to exclusion and discrimination and therefore infringes upon children's rights. ${ }^{21}$ Meanwhile, public and private institutions throughout the Netherlands have started to change Black Pete's appearance or have dismissed the character entirely. ${ }^{22}$

\section{Identity crisis}

Fierce public debate on issues such as Johan Maurits's bust and Black Pete seem to be the signs of an identity crisis that the Netherlands is currently dealing with in a globalizing world. The Dutch tend to think of themselves as the happy members of 'a small, but just, ethical nation (...) being inherently on the moral and ethical high ground, thus serving as a guiding light to other folks and nations. ${ }^{23}$ Typically, they congratulate themselves with their progressive liberal mind-set, tolerant towards minorities and taking a particularly enlightened and pragmatic

16 For a useful overview of recent discussions and upheavals, see esp. Wekker, White Innocence, 139-67.

17 Working Group on people of African descent, letter of January 17, 2013, see https://spdb.ohchr. org/hrdb/23rd/public_-_AL_Netherlands_17.01.13_\%281.2013\%29.pdf (accessed February 23, 2018).

18 Just Fontein, 'Hoofd VN-onderzoek: Zwarte Piet is terugkeer slavernij,' de Volkskrant, October 22, 2013 reporting on the interview Shepherd gave to Dutch television news show EenVandaag. Her comments were also picked up by international media, see, e.g., Erik Voeten, 'Black Pete and the United Nations,' Washington Post, October 22, 2013.

19 Wekker, White Innocence, 149.

20 'Rutte: sinterklaasfeest is geen zaak van de politiek,' de Volkskrant, July 4, 2014. See also Tara John, Time Magazine, December 9, 2015.

21 Dutch Childrens' Ombudsman, position paper of September 30, 2016, available in Dutch and English at www.dekinderombudsman.nl.

22 See, e.g., Eva de Valk, 'Hema doet Zwarte Piet in de ban,' NRC Handelsblad, August 26, 2014; for international coverage on this development, see, e.g., Ted Thornhill, 'Dutch Abandon "Black Pete” Christmas Tradition over Racism Row,' Daily Mail, October 16, 2014. 
approach towards drugs, abortion and euthanasia. ${ }^{24}$ Purportedly too powerless to play a decisive role on the global scale, the Dutch usually see themselves as the innocent witnesses of historical events rather than accepting their full responsibility for their role as active participants in it. ${ }^{25}$ That self-indulgent image has been severely challenged in recent years. Supporting a critical report of the Council of Europe, for example, national ombudsman Brenninkmeijer described the Dutch political climate as outright discriminatory, with all sides of the political spectrum suffering from a persistent blindness to an 'institutional racism' that would pervade society. ${ }^{26}$ Meanwhile, the Dutch myth of helpless and innocent bystandership has been contested in court cases on a variety of subjects, ranging from the Dutch failure to prevent the Srebrenica massacre, ${ }^{27}$ war crimes committed by Dutch troops in Indonesia ${ }^{28}$ and the restitution of expropriated properties in the aftermath of the German occupation in World War II. ${ }^{29}$

How should the Dutch come to terms with their troublesome past and their ambiguous cultural heritage? The heated public debate as it is currently waged seems to discern only two opposing ways forward. First, there are those who tend to follow Baudet in dismissing any critique on the Dutch colonial past or its cultural traditions as a dangerous manifestation of 'oikophobia,' or, in a wider sense, as Leiden professor Paul Cliteur has it, of 'occidentophobia,' a disturbed selfhatred against anything Western, a pathological disregard of Western values and principles that could ultimately lead to nothing less than 'cultural suicide. ${ }^{30} \mathrm{Sec}$ ond, there are others who aim to debunk the Dutch 'cultural archive' as a racist and sexist frame of reference in which violent tendencies of repression and exclusion have been heavily cemented and sedimentized, with its dominant self-representation of an enlightened progressive liberalism serving merely as an outward

24 The Dutch tradition of enlightened tolerance is often traced back to the Dutch Golden Age in early-modern history, celebrating the freedoms of expression and religion as they were championed by thinkers such as Grotius and Spinoza. See, e.g., Wijnand Mijnhardt, 'A Tradition of Tolerance,' in Discovering the Dutch: On Culture and Society of the Netherlands, eds. Emmeline Besamuca and Jaap Verheul (Amsterdam: Amsterdam University Press, 2014), 121-32.

25 Wekker, White Innocence, 12-13.

26 See Hassan Bahara, 'Wij willen niet Nederland bashen,' Groene Amsterdammer, December 3, 2014 for a good overview of the discussion on Dutch 'institutional racism' as it was provoked by Brenninkmeijer's comments in Dutch political television show Buitenhof on October 7, 2013.

27 Supreme Court September 6, 2013, ECLI:NL:HR:2013:BZ9225, JB 2013/197; Court of Appeal of The Hague June 27, 2017, ECLI:NL:GHDHA:2017:1761.

28 District Court of The Hague September 14, 2011, ECLI:NL:RBSGR:2011:BS8793; District Court of The Hague January 27, 2016, ECLI:NL:RBDHA:2016:701.

29 See, e.g., Wouter Veraart, 'Two Rounds of Postwar Restitution and Dignity Restoration in the Netherlands and France,' Law \& Social Inquiry 41, no. 4 (2016): 956-72, with special regard to the 'second round' - now less formalistic - of restitution of property rights of the Jewish population in the Netherlands and France that started in the late 1990s.

30 Paul Cliteur, 'Over occidentofobie: haat tegen westerse cultuur,' ThePostOnline, August 2, 2017, see http://politiek.tpo.nl/column/prof-paul-cliteur-over-occidentofobie-haat-tegen-westersecultuur/(accessed February 24, 2018). Cf., e.g., Jalees Rehman, 'Occidentophobia: The Elephant in the Room,' Guernica Magazine, September 26, 2011, see www.guernicamag.com/jalees_ rehman_occidentophobia8/(accessed February 24, 2018). 
appearance. ${ }^{31}$ For example, such a stance has been taken up by Denk ('Think') and Artikel 1 ('Article 1,' referring to the Constitution's prohibition of discrimination) as two new political parties specifically devoted to the protection of the rights of immigrants and other minorities. ${ }^{32}$ Standing up against what they see as underlying patterns of exclusion and discrimination in Dutch society, the leaders of both these parties and their activist allies have been confronted with a tremendous amount of aggression on social media and also with more physical expressions of hostility, including the blocking of a national highway preventing a law-abiding group of protesters to demonstrate against Black Pete. ${ }^{33}$

Worried about the climate of polarization and imminent violence that surrounds the debate on Dutch culture and history, a group of students from Utrecht University recently started a media campaign designed to create 'room for nuance' and to 'build bridges' between opposite sides by drawing attention to 'the grey middle in between the extremes of black and white.' 34 Their manifesto 'Dare to be Grey' was widely embraced by leading public intellectuals such as national 'thinker laureate' ('Denker des Vaderlands') René ten Bos and historian James Kennedy, with the latter more or less melancholically remembering the grey spirit of nuanced consensus that characterized pre-9/11 Dutch politics. ${ }^{35}$ There is no doubt that a call for more nuance and 'greyness' is important in a time in which many members of opposing political camps seem to have withdrawn in their own filter bubbles, constantly being affirmed in their opinions while also affirming those of like-minded others in their bubble. In today's polarized political climate, there seems to be little in between the uncritical acceptance of our 'enlightened Western heritage' on the one hand and the cynical renunciation of that same heritage on the other hand. Public debates tend to confront us with all kinds of unsatisfying choices, inviting us, for example, either to uncritically embrace the hegemonic narrative of a 'Western tradition of enlightened Judeo-Christian humanism'36 or to unmask that tradition as a false vehicle for exclusion and vio-

Wekker, White Innocence, 2-3.

32 Whereas Denk focuses on the rights of immigrants, Article 1 (now Bij1) stands up for the rights of minorities more in general. Denk obtained three seats in the parliament, Article 1 received a lot of media attention but did not succeed in passing the electoral threshold of 1/150th of the total number of valid votes. For an insightful foreign report on Denk's electoral success, see Selwyn Duke, 'With Dutch-Islamist “Denk” Party, Immigrants Rebel Against Assimilation,' The Observer, March 29, 2017.

33 The blocking of the motorway in the northern province of Friesland caused great upheaval and was proudly described by the protesters themselves as well as by many pro-Pete media as a modern 'battle of Friesland,' on a par with the heroic expulsion of the troops of the Count of Holland in 1345. For international coverage, see, e.g., Samira bin Sharifu, 'Black Pete: Extreme Right Appears to Stoke Dutch Divisions,' The Guardian, November 28, 2017.

34 See www.dtbg.nl.

35 James Kennedy, 'Tijd dat het “grijs” weer terugkomt in de politiek,' Trouw, April 17, 2016.

36 Sybrand Buma, 'Verwarde tijden,' Elsevier Weekblad, September 4, 2017, i.e. the published version of a public lecture on September 4 by the leader of the Christian Democrats in the Dutch parliament. 
lent repression. ${ }^{37}$ But what about the 'grey middle ground' in between those opposites?

\section{Tragic Ambiguity}

Though valuable in itself, the search for a nuanced balance has the disadvantage of repressing the many unresolved antagonisms and incongruities of Dutch cultural identity, attempting to harmonize its insoluble paradoxes into a 'grey middle' in which its deeply ambiguous nature remains unnoticed. A dominant modern logic built on the principles of identity and non-contradiction seems to preclude the possibility of thinking of the Saint Nicholas tradition as, in a way, an innocent children's feast and a harmful expression of institutionalized racism, unable to accept the idea that anything could have opposing and logically irreconcilable characteristics at the same time. ${ }^{38}$ Thus, that dominant logic forces us to see that tradition either the one or the other way, or, as a third alternative, to opt for some grey balance as a depolarized 'middle ground' in between. But could we also continue to appreciate the Dutch tradition of tolerance and enlightened progressivism while simultaneously acknowledging and resisting its tendencies towards uncritical self-indulgence or even to exclusion and repressive normalization? Could we value and maybe even cherish the exploits and wise policies of Johan Maurits in Dutch Brazil without being blind for his seminal contribution to the transatlantic slave trade? Could the Mauritshuis leave the copy of his bust designed to celebrate Maurits's purported greatness - in its lobby without walking away for its responsibilities towards those who feel oppressed by that gesture? Asking ourselves how to deal with our ambiguous past and being upset by the many insoluble contradictions within our cultural identity, help may come from a surprising source: Greek tragedy.

Unlike the logocentric bent of much of modern philosophy, Greek tragedy neither denies the paradoxes that come with human existence nor aims to neutralize its unsolvable dilemmas by sweeping them under the carpet of a 'golden mean,' a mysterious ethical 'synthesis,' a 'right balance' or some other harmonizing principle. ${ }^{39}$ Instead, it has the ambiguous nature of culture and political society at its very core. ${ }^{40}$ The famous 'Ode to Man' in Sophocles's Antigone is a prime expres-

37 Willem Schinkel, 'The Imagination of Society in Measurements of Immigrant Integration,' in The Language of Inclusion and Exclusion in Immigration and Integration, ed. Marlou Schrover and Willem Schinkel (London: Routledge, 2014), 20-39, esp. 31-32. Cf. also Janneke Stegeman and Alain Verheij, 'Manifest voor een christendom zonder moslimhaat,' available at www.nieuwwij.nl.

38 Cf. Jacques Derrida, Dissemination, trans. Barbara Johnson (Chicago: Chicago University Press, 1981), esp. the essay 'Plato's Pharmacy' (65-171) revolving around the ambiguity of the Socratic pharmakon as beneficial drug and harmful poison.

39 Cf. Lukas van den Berge, 'Sophocles' Antigone and the Promise of Ethical Life: Tragic Ambiguity and the Pathologies of Reason,' Law and Humanities 11, no. 2 (2017), 205-27.

40 See esp. Theodoor Oudemans and André Lardinois, Tragic Ambiguity: Anthropology, Philosophy and Sophocles' Antigone (Leiden: Brill, 1987), describing the 'logic of ambiguity and insoluble paradox' that pervades Aeschylean and Sophoclean tragedy. 
sion of this. It describes man as a most 'awesome' (deinos) being, with the original Greek adjective carrying strong positive and negative connotations at the same time. ${ }^{41}$ In his 'awesomeness,' man is daring enough to 'cross the grey sea,' even through the surging waves of winter (335-337). In skilful use of his many artful contrivances (technai), he, 'man excellent in wit,' typically aims to master nature, scourging 'Earth, the eldest of the Gods' with his plough and taming and catching wild animals with his nets and all his other smart devices (338-354). In similar fashion, man possesses a political art (technē) that enables him to build cities as political societies that facilitate his survival in wild nature (355-58). Man's use of his artful contrivances, however, comes with the inherent danger of hybris and self-destruction, with the very same technai that facilitate human existence inevitably also threatening it (365-375). Therefore, man - as well as the cultured political environment that he has created - is deinos in the full ambiguity of that word: wonderful and awful, uplifted and transgressive, life-fostering and life-threatening, good and bad all at the same time, without any outlook on a harmonizing balance, a 'grey middle' or some other way to evade that double and incongruous nature. ${ }^{42}$

'The city that shelters us from savagery provides little security from the savagery within us,' Christopher Rocco - in his important book on Greek tragedy and political philosophy - aptly remarks with regard to Sophocles's Oedipus Tyrannos. ${ }^{43}$ Resembling that play's main protagonist, Johan Maurits was probably unaware of the violent and unethical nature of the purportedly so enlightened regime that he established. Even in the neo-stoic humanist circles in which Maurits participated, there were only few who questioned the ethical admissibility of the Dutch slave trade already at its onset in the early 1600s. Barlaeus, in fact - Maurits's very own hagiographer - was one of them, regarding 'the buying and selling of human beings created in God's likeness' as an activity in which a 'wise merchant' (mercator sapiens) should be careful to participate. But even Barlaeus accepted the transatlantic slave trade as nothing to be bothered about, arguing that the slaves from Africa would have been 'subject to slavery due to a defect of their nature,' lacking the intelligence and skills 'to accomplish anything worthy of mankind. ${ }^{44}$ Maurits was thus most probably blind for the destructive forces underlying the humanist and tolerant legal and political order that he so proudly established on a distant shore. Depending on progressivist and enlightened insights that prevailed at the time, he aimed to create a civilized environment that is separated from savage

41 Literature on the 'Ode to Man' is vast; among its interpreters are not only classicists, but also writers and philosophers like Hölderlin, Hegel, Kierkegaard, Heidegger and Lacan. See Douglas Cairns, Sophocles: Antigone (London: Bloomsbury, 2016), 59 ff. for an overview of classical scholarship and $122 \mathrm{ff}$. for a handsome summary of its philosophical reception.

42 Van den Berge, 'Sophocles' Antigone,' 223-25, with further references. See also Oudemans and Lardinois, Tragic Ambiguity, 120-31 and 214-21, particularly resisting 'harmonizing' approaches to tragedy such as those of Aristotle, Hegel and Ricoeur.

43 Christopher Rocco, Tragedy and Enlightenment: Athenian Political Thought and the Dilemmas of Modernity (Berkeley: University of California Press, 1997), 38.

44 Barlaeus, The History of Brazil, 179-81; see also Ineke Phaf, The 'Air of Liberty': Narratives of the South Atlantic Past (Amsterdam and New York: Rodopi, 2008), 33-34, with further references. 
nature. Not unlike Oedipus, however, he finally turns out to be embody an ambiguous unity of opposites, representing superior rationality and dreadful ignorance, cultured civilization and naked bestiality, enlightened progress and unreflected use of violence all at the same time.

At the end of Sophocles's great play, it seems clear what should happen to a ruler who seemed to be a semi-divine saviour of the city but is finally exposed as a dangerous source of pollution - both king and scapegoat, the awesome slayer of the Sphinx and intelligent enough to solve the monster's riddle, but ignorant about his own identity as '[his] own father's killer and bridegroom to her that gave [him] birth' (1357-1359). In the final scene, Oedipus emerges on stage from his house, having blinded himself, now seeing what he should have seen while still in possession of his sight. As a subject 'thrice accursed, most hated by the gods' (1344-1345), he begs the citizens to 'hide him somewhere in the wild, kill him, or hurl him into the sea' (1410-1412), regarding his immediate expulsion from the city as the only way in which it may be cured from a terrible disease. Oedipus's departure, however, never comes - not, at least, within the play's unfolding plot. Instead, the drama closes with Oedipus being sent back into the royal palace, leaving us with his 're-entry into a house that has already seen too much." ${ }^{\text {" }}$ That unexpected and disconcerting end may be taken to signify the impossibility of an easy closure, the unfeasibility of a comfortable expulsion by society from anything polluted in order to be cleansed from dangerous wild forces and unsettling ambiguities. In similar fashion, it may be too optimistic to expect too much from the expulsion of Maurits's bust from the lobby of the Mauritshuis. As long as it serves not only as a paradigm for the many ambiguities of our history and our cultural heritage, but also as an uneasy reminder of the need for constant reflection on possible blind spots from which we ourselves may suffer, it may be a good idea to give it a prominent place in the public realm.

\section{Conclusion: the acceptance of tragedy}

Like no other literary genre, ancient Greek tragedy draws attention to the insoluble dilemmas and paradoxes that come with human existence, hampered by an inevitable lack of rational oversight and determined by a logic of ambiguity and contradiction rather than clear-cut rational principles. No wonder, therefore, that tragedy is banished from Plato's ideal city as a dangerous source of malady, challenging the hegemony of reason both in the soul and the political community. ${ }^{46}$ As a more insidious and therefore even more dangerous enemy of tragedy, Aristotle incorporates tragedy in his ideal political community while suppressing its disturbing and ambiguous character. Awarding tragedy a significant place in the ethical education (paideia) of citizens and describing it as a therapeutic instrument of ment, 61.

46 See, e.g., Raymond Barfield, The Ancient Quarrel between Poetry and Philosophy (Cambridge: Cambridge University Press, 2011) 10ff, with further references. 
healing and purification (katharsis), Aristotle may be seen as the intellectual father of those who tend to regard tragedy as an important source of ethical knowledge (phronēsis), supposedly sharpening proper moral judgment while in fact it merely exposes the infeasibility of such judgment. ${ }^{47}$ Only thinkers such as Nietzsche and Heidegger, with their approaches to tragedy further developed by the likes of Schmitt, Agamben, Deleuze and Žižek, have returned to the full philosophical acceptance of tragedy. ${ }^{48}$ Subscribing to the discomforting insight that the rule of law is inevitably caught in a chronotope of irrational violence, requiring a foundational moment of mere force and necessarily excluding others with every act of inclusion at its real or imagined borders, these thinkers have finally rediscovered the inevitable ambiguous 'awesomeness' (deinotēs) of human existence, cultured and wild, reasoned and irrational, righteous and wrongful all at the same time.

With the crisis of Dutch cultural and political identity in full swing, the acceptance of man's ambiguous awesomeness may open up a complex and difficult, but nevertheless attractive way out of an unproductive debate that only tends to recognize three unrewarding options: either total deconstruction or uncritical persistence in the hegemonic narrative or else some grey middle in between. The recognition of 'tragic ambiguity' as a fourth alternative allows for the positive assessment of Johan Maurits's wise policies without remaining blind for his contribution to the Dutch slave trade. It enables the continued appreciation of our cultured environment - always in flux, of course - without being naive or wilfully ignorant about its inevitable side-effects of exclusion and oppression. Of course, the acceptance of tragedy should not in any way serve as a pretext for easy relativism, settling for the idea that the inevitability of political and ethical violence releases us from a constant search for amendments and improvements to our legal and cultural order. Instead, it should spur us to continuous self-critical examination of the rational principles and cultural patterns by which we operate, while also acknowledging that we need at least some of such principles and patterns to create a structured environment that saves us from the chaos of wild nature. The concept of 'tragic ambiguity' creates room for careful reflection and nuance without opting for a depolarized 'middle' that suppresses the many unresolvable antagonisms and paradoxes that lie at the heart of Dutch society - as, in fact, such antagonisms and paradoxes are foundational to any cultural and political society.

48 See Julian Young, The Philosophy of Tragedy: From Plato to Žižek (Cambridge: Cambridge University Press, 2013) for a handsome overview of tragedy's philosophical reception, ranging from antiquity up to postmodernism. 